https://doi.org/10.52058/2786-4952-2022-1(6)-109-121

Вікторенко Ірина Леонідівна доктор педагогічних наук, доцент, Державний вищий навчальний заклад «Донбаський державний педагогічний університет», вул. Університетська, 12, м. Слов'янськ, 84116, тел.: (050) 773-73-09, https://orcid.org/0000-0003-3887-4662

Федь Ірина Свгенівна кандидат педагогічних наук, доцент, Державний вищий навчальний заклад «Донбаський державний педагогічний університет», вул. Університетська, 12, м. Слов'янськ, 84116, тел.: (095) 049-11-51, https://orcid.org/0000-0002-4058-2047

Каюда Надія Іванівна здобувач початкової освіти, Державний вищий навчальний заклад «Донбаський державний педагогічний університет», вул. Університетська, 12, м. Слов'янськ, 84116, тел.: (095) 895-64-14

\title{
ФОРМУВАННЯ СОЦІАЛЬНОЇ ТА ГРОМАДЯНСЬКОЇ КОМПЕТЕНТНОСТЕЙ ЗДОБУВАЧІВ ПОЧАТКОВОЇ ОСВІТИ (НА ПРИКЛАДІ КУРСУ «Я ДОСЛІДЖУЮ СВІТ»)
}

Анотація. У соціально-економічних і політичних реаліях, що склалися в країні, формування соціальної та громадянської компетентностей у здобувачів початкової освіти є однією з провідних напрямів розвитку системи освіти. Нашому суспільству потрібні свідомі громадяни, які поважають закон і державу, які вміють користуватися особистими свободами, готові до співпраці та соціальної взаємодії, які мають соціальні та громадянські якості, почуття відповідальності за долю країни, які компетентно беруть участь у демократичних процесах. Соціальна потреба у підготовці школярів до активної участі у суспільно-політичному житті країни, до ефективної соціально корисної діяльності в умовах демократичної правової держави зумовлює необхідність здійснення у закладах освіти соціальної та громадянської освіти учнів, формування у них соціальної та громадянської компетентностей.

На всіх історичних етапах розвитку освіти школа була і продовжує залишатися найважливішим ресурсом виховання підростаючого покоління. Саме у шкільні роки дитина стає особистістю, у неї формуються цінності, які визначатимуть iï ставлення до себе та світу, впливатимуть на іiі вчинки та поведінку в цілому. I саме педагогу, відводиться важлива роль у формуванні активної соціальної та громадянської позиції, яка полягає у тому, щоб визначити форми та методи взаємодії, допомогти дітям знайти себе в житті, самовизначитися, прищепити навички, які допомогли 6 успішно функціонувати у світі. 
Соціальна та громадянська освіта реалізується послідовно на всіх етапах навчання та за допомогою всіх навчальних предметів, і в першу чергу, в курсі «Я досліджую світ» як засобу формування основ соціальної та громадянської позиції здобувача початкової освіти. Для досягнення мети - формування засад соціальної та громадянської позиції здобувача початкової освіти у курсі «Я досліджую світ» - було сформульовано такі завдання: забезпечення здатності до осмислення понять та оволодіння знаннями про соціальні та громадянські цінності (Людина, Сім'я, Батьківщина тощо); формування усвідомленого прийняття цінностей та стійке емоційно-чуттєве ставлення до них.

Отже, формувати соціальну та громадянську позиції у підростаючого покоління можна лише за умови реалізації єдиної освітньої системи, у якій завдання, механізми, методи, принципи виховання підпорядковані єдиній меті - виховання культурної людини, громадянина і патріота.

Ключові слова: компетентність, компетентнісний підхід, громадянськість, соціальна та громадянська компетентності, демократична держава, освіта для демократичного громадянства.

Viktorenko Iryna Leonidivna Doctor of Pedagogical Sciences, Associate Professor, Donbass State Pedagogical University, University St., 12, Slovyansk, 84116, tel.: (050) 773-73-09, https//orcid.org/0000-0003-3887-4662

Fed Iryna Yevhenivna Candidate of Pedagogical Sciences, Associate Professor, Donbass State Pedagogical University, University St., 12, Slovyansk, 84116,tel.: (095) 049-11-51, https//orcid.org/0000-0002-4058-2047

Kayuda Nadiya Ivanivna Applicant for primary education, Donbass State Pedagogical University, University St., 12, Slovyansk, 84116,tel.: (095) 895-64-14

\section{FORMATION OF SOCIAL AND CIVIC COMPETENCIES OF PRIMARY EDUCATION STUDENTS (ON THE EXAMPLE OF THE COURSE «I EXPLORE THE WORLD»)}

Abstract. In the socio-economic and political realities prevailing in the country, the formation of social and civic competencies in primary school students is one of the leading directions in the development of the education system. Our society needs conscious citizens who respect the law and the state, who know how to enjoy personal freedoms, who are ready for cooperation and social interaction, who have social and civic qualities, a sense of responsibility for the country's destiny, who competently participate in democratic processes. The social need to prepare students for active participation in the socio-political life of the country, for effective socially useful activities in a democratic state governed by the rule of law necessitates the implementation of social and civic education in educational institutions, formation of social and civic competencies. 
At all historical stages of educational development, the school has been and continues to be the most important resource for educating the younger generation. It is during the school years that a child becomes a person, values are formed in him, which will determine his attitude to himself and the world, will influence his actions and behavior in general. And it is the teacher who plays an important role in forming an active social and civic position, which is to determine the forms and methods of interaction, help children find themselves in life, self-determination, instill skills that would help to function successfully in the world.

Social and civic education is implemented consistently at all stages of learning and with the help of all subjects, and especially in the course "I explore the world" as a means of forming the foundations of social and civic position of primary school students. To achieve the goal - forming the foundations of social and civic position of primary school students in the course "I explore the world" - the following tasks were formulated: ensuring the ability to comprehend concepts and master knowledge of social and civic values (Man, Family, Motherland, etc.); formation of conscious acceptance of values and stable emotional and sensory attitude to them.

Thus, to form a social and civic position in the younger generation is possible only if the implementation of a single educational system in which tasks, mechanisms, methods, principles of education are subject to a single goal - the education of a cultured person, citizen and patriot.

Keywords: competence, competence approach, citizenship, social and civic competences, democratic state, education for democratic citizenship.

Постановка проблеми. У суспільстві на початку XXI століття відбулися кардинальні державно-політичні та соціально-економічні перетворення. Наша країна йде шляхом побудови демократичної держави та становлення громадянського суспільства, удосконалення всіх сфер життя людини та громадянина. Успіхи на цьому шляху залежать не тільки від розвитку економіки, удосконалення законодавства та модернізації правових відносин, а й від громадянської відповідальності та компетентності особистості, якими визначається рівень готовності молодого покоління до гідних відповідей на історичні виклики.

Актуальність проблеми становлення соціальної та громадянської компетентностей учнівської молоді визначається ще й докорінними змінами в організації освітнього середовища, внаслідок чого сучасна молодь швидко включається до хаосу освітнього Інтернет-простору, отримує вільний доступ до величезної кількості каналів розважального телебачення, що призводить до втрати соціальних орієнтирів у значної частини підростаючого покоління, яка найчастіше свої життєві настанови та перспективи бачить крізь призму «віртуальних світів» та сумнівних цінностей масової культури. Внаслідок цього у середовищі молоді стали частіше спостерігатися прояви асоціальної поведінки, сучасне покоління все меншою мірою стає носієм громадянських якостей у повному обсязі та не готове брати участь у побудові демократичного 
Журнал«Герспективитаіновації наукиљ

(Серія«Гедагогіка», Серія«ГЕихологія», Серія«Медицина»

№1(6) 2022

суспільства внаслідок несформованості громадянських та патріотичних орієнтирів. Усе це свідчить про те, що чимала частина молоді характеризується низьким рівнем сформованості соціальної та громадянської компетентностей. Усвідомлення перелічених вище обставин підвищує вимоги до виховної діяльності у закладах освіти, передбачає розробку та вдосконалення технологій управління виховним процесом, причому процес становлення соціальної та громадянської компетентностей підростаючого покоління може стати одним із основних механізмів, що дозволяють підвищити якість професійної підготовки майбутніх фахівців.

Аналіз останніх досліджень і публікацій. Проблема соціального та громадянського виховання підростаючого покоління завжди привертала увагу вчених, оскільки, по суті, молодь завжди несла особливу відповідальність за сучасне та майбутнє держави, за збереження та розвиток суспільства, за спадкоємність культури, за рівень життя старших поколінь та відтворення нових. Віра в Україну та міркування про завтрашній день українців, ціннісні орієнтації суспільства, національну безпеку країни завжди були і залишаються пов'язаними з питаннями виховання, оскільки коріння творчого розвитку, соціального та громадянського становлення підростаючого покоління криються, насамперед, у вихованні, у тому числі й у вихованні фахівця. Адже саме ті молоді люди, які сидять зараз у закладах освіти, незабаром стануть на чолі країни, визначатимуть їі долю та впливатимуть на світовий розвиток.

У контексті сучасних суперечок про цілі та завдання виховання молодого покоління не втрачає актуальності вітчизняна філософська спадщина. Аналіз понять «громадянськість», «громадянський обов'язок», «патріотизм» та інших часто можна зустріти у творах Н. А. Бердяєва, С. М. Булгакова, І. А. Ільїна, В. В. Розанова, Н. І. Пирогова, П. А. Флоренського та інших вітчизняних учених. У їхніх працях проголошується абсолютна цінність особистості, іiі право на творчу свободу, які можуть бути досягнуті лише як результат виховання громадянина. У разі сучасного розвитку світової спільноти ці положення стають особливо значущі. Сучасному поколінню - майбутнім фахівцям, з одного боку необхідно бути психологічно та практично готовими до змін, що відбуваються в глобальній спільноті, а 3 іншого - до зростаючої соціальної відповідальності за долі країни та самостійності поведінки в межах моральних та правових норм. Саме на навчальні заклади покладено особливу історичну відповідальність за розвиток соціальної та громадянської позицій молоді, а роль освіти в цих умовах незмірно зростає.

У дисертаційних дослідженнях останніх років розглядаються різні аспекти та проблеми соціального та громадянського виховання підростаючого покоління: сутності соціальної компетентності особистості в цілому (Д. Бартемле, О. В. Варецька, С. З. Гончаров, . Б. Зарубінська, С. М. Краснокутська, В. В. Москаленко, А. К. Мудрик, П. У. Каннінг, В. М. Шахрай, Х. Шулер), історико-педагогічний (В. І. Блінов, А. П. Булкін, О. І. Волжина, JI. В. Кузнєцова, І. Ю. Синельников. Також у дослідженнях 
вивчені шляхи та засоби громадянського виховання (А. В.Бєляєв, А. С. Гаязов, Г. Я. Гревцева, Р. Г. Гурова, Т. В. Гурська, І. М. Дуранов та ін.), питання формування громадянських якостей у учнівської молоді (С. В. Анохін, І. Ю. Буланов, В. М. Власова, І. М. Дуранов, В. В. Мартинова, Т. Н. Османкіна, Т. В. Панаріна, О. І. Шаталович та ін.), формування громадянськості засобами різних навчальних дисциплін (Г.Я.Гревцева, Л. Б. Доржієва, Є. М. Карпаніна, Н. Ф. Крицька, І. М. Кондратенко, А. Ф. Нікітін, Ф.Х. Сахапова, М. Г. Чесняк, О. Р.Шефер та ін.). У дослідженнях розглянуто питання підготовки майбутнього вчителя до громадянського виховання (Т. М. Абрамян, С. В. Митросенко, О. П. Пєсоцька, Л. В. Скорикова та ін.), виявлено педагогічні умови ефективного виховання громадянськості (А. М. Бабаєв, Є. В. Бондаревська, Н. І. Васильєв, А. С. Гаязов, І. М. Дуранов, Ю. А. Танюхін, Д. С. Яковлєва та ін.).

Ряд досліджень присвячено вивченню формування громадянської позиції особистості 3 опорою на національні традиції та культурні цінності (Н. І. Васильєв, С. М. Данинов, І. І. Павлова та ін.), проблеми духовноморального виховання підростаючого покоління (Г. М. Іонова, I. М. Кондратенко, І. С. Марьєнко, Т. І. Петракова, I. В. Саванович та ряд інших авторів).

Особливий інтерес представляють дослідження, статті, пов'язані 3 розглядом проблем становлення громадянського суспільства, ціннісних орієнтацій, громадянської культури, громадянської свідомості, громадянської активності, громадянської соціалізації (Т. В. Болотіна, К. С. Гаджієв, Г. Г. Ділігенський, О. В. Заславська, . Я. Капустіна, Ю. А. Красін, В. К. Левашов, В. Т. Лісовський, І. Д. Лаптєва, В. М. Межуєв, В. А. Міжеріков, Т. М. Самсонова, А. І. Соловйов, К. Г. Холодковський та ін.). Великий внесок у теорію громадянського суспільства та громадянського виховання зробили сучасні зарубіжні автори (Г. Алмонд, Е. Арато, М.Бренсон, Р. Патнем, А. Селігман, С. Шехтер та ін. Вони орієнтують на організацію виховання підростаючого покоління у дусі гуманізму, відродження духовного та морального потенціалу будь-якої нації, виховання громадянина за умов вільного, відкритого суспільства. До обов'язкових якостей громадянина відносять моральну відповідальність, самодисципліну, повагу до закону, здатність та бажання йти на компроміс, повагу до гідності кожної людини.

Особливо значущим стало вивчення психолого-педагогічних досліджень, присвячених питанням впровадження в освітній процес компетентнісного підходу, становленню та розвитку компетентностей - професійної, інформаційної, комунікативної, правової, дослідницької, соціальної, громадянської, загальнокультурної та ін. Сутність компетентнісного підходу, проблеми формування ключових компетенцій, зміст поняття «компетентність» аналізуються у роботах вітчизняних та зарубіжних авторів (А. Л. Андрєєва, В. І. Байденко, О. Г. Бермус, І. А. Зимньої, А. М. Князєва, О. С. Лебедєва,
А. К. Маркової,
Г. К. Селевко,
В. В. Серікова,
С. Б. Серякової, 

А. М. Тубельського
I. C. Фішмана,
І. Д. Фруміна,
А. В. Хуторського, В. М. Шепеля, Б. Д. Ельконіна, Р. Даля, Дж. Равена, Х. Мюнклера та ін.

Таким чином, аналіз наявних робіт та досліджень із різних аспектів та проблем соціальної та громадянської освіти, виховання та компетентнісного підходу дозволяє зробити висновок, що в даний час проблема формування соціальної та громадянської компетентностей взагалі, а учнівської молоді особливо є однією зі слабо розроблених у вітчизняній літературі.

Мета статті. Обгрунтування необхідності формування соціальної та громадянської компетентностей у процесі навчання підростаючого покоління.

Виклад основного матеріалу. Сучасний період у історії та освіті держави характеризується усвідомленням необхідності виховання високоморального творчого, компетентного громадянина України, який приймає долю Батьківщини як свою особисту, усвідомлює відповідальність за сьогодення та майбутнє своєї країни, такого громадянина потрібно озброїти не лише глибокими та міцними знаннями про громадянські цінності, а й забезпечити готовність до суспільно-значущої діяльності. На етапі початкової освіти закладаються основні моральні цінності, норми поведінки, починається формування особистості, яка усвідомлює себе частиною суспільства та громадянином своєї Батьківщини. Розвиваються комунікативні здібності дитини, які дозволяють їй інтегруватися до спільноти, сприяють формуванню вміння вирішувати конфліктні ситуації через діалог. Молодший шкільний вік характеризується мотиваційною готовністю до прийняття зовнішнього впливу, позитивним ставленням до даного впливу та наявністю потреби в досягненнях у конкретній галузі знань чи діяльності. Цей вік $є$ найбільш сприятливим для емоційно-психологічного впливу на дитину, оскільки образи сприйняття культурного простору яскраві і сильні, тому вони надовго залишаються у пам'яті.

Соціальні компетентності поруч із громадянськими включені до восьми основних компетентностей для навчання протягом усього життя Рекомендаціями Європейського Парламенту та Ради (СС) від 18 грудня 2006 року. Правові основи соціальної та громадянської освіти в Україні закладені у Конституції України, Законі України «Про освіту»; Національній стратегії сприяння розвитку громадянського суспільства в Україні на 20162020 роки, затвердженій Указом Президента України від 26 лютого 2016 р. №68; Стратегії національно-патріотичного виховання дітей та молоді на 20162020 роки, затвердженій Указом Президента України від 13 жовтня 2015 р. №580; Національній стратегії у сфері прав людини, затвердженій Указом Президента України від 25 серпня 2015 р. № 501.3 прийняттям нового Закону України «Про освіту» та 3 урахуванням Указу Президента України від 1 грудня 2016 р. № 534 «Про пріоритетні заходи щодо сприяння зміцненню національної єдності та консолідації українського суспільства, підтримки ініціатив громадськості у цій сфері», плану заходів щодо зміцнення національної єдності, консолідації українського суспільства та підтримки 
ініціатив громадськості у зазначеній сфері, затвердженого розпорядженням Кабінету Міністрів України від 21 березня 2018 р. № 179, виникла необхідність визначення конкретних кроків на шляху формування соціальної та громадянської освіти в Україні.

Закон України «Про освіту» визначає, що держава створює умови для здобуття соціальної та громадянської освіти, спрямованої на формування компетентностей, пов'язаних із реалізацією особистістю своїх прав i обов'язків як члена суспільства, усвідомленням цінностей громадянського (вільного демократичного) суспільства, верховенства права, прав і свобод людини і громадянина. Правовою підставою для формування соціальної та громадянської компетентностей на рівні загальної середньої освіти є стаття 12 Закону України «Про освіту», яка визначає 12 ключових компетентностей, зокрема соціальні та громадянські компетентності, пов'язані 3 ідеями демократії, справедливості, рівності, прав людини, добробуту та здорового способу життя, з усвідомленням рівних прав і можливостей, що відповідають меті та принципам освіти, і додатково - наскрізні компетентності, зокрема критичне мислення.

Відповідно до Концепції реалізації державної політики у сфері реформування загальної середньої освіти «Нова українська школа» на період до 2029 року, схваленої розпорядженням Кабінету Міністрів України від 14 грудня 2016 р. № 988, до соціальної та громадянської компетентностей належать усі форми поведінки, які потрібні для ефективної та конструктивної участі у громадському житті, в сім'ї, на роботі; уміння працювати з іншими на результат, попереджати i розв'язувати конфлікти, досягати компромісів; повага до закону, дотримання прав людини і підтримка соціокультурного різноманіття.

Наприкінці 60-х років XX століття німецьким ученим Г. Ротом був уведений термін «соціальна компетентність». Так, ним виокремлено три види компетентності людини, що забезпечують іiі успішну життєдіяльність: самокомпетентність(знання самого себе), соціальна компетентність (взаємодія 3 іншими), предметна компетентність (практична діяльність) [2]. Саме таке розуміння соціальної компетентності стало підгрунтям іiі подальших досліджень.

Згідно із Рекомендаціями ради Європи щодо ключових компетентностей для освіти впродовж життя від 17.01 .2018 р., соціальна компетентність визначається спроможністю людини здійснювати рефлексію щодо своєї діяльності, ефективно управляти часом та соціальною інформацією, працювати 3 іншими в конструктивний спосіб, бути стійким та управляти своєю кар'єрою.

Як зазначено у документі, вона включає в себе здатність давати собі раду зі складнощами й невизначеністю, співчувати та управляти конфліктними ситуаціями та забезпечується: знаннями, як-то: правила поведінки й спілкування, що є загальноприйнятими в різних суспільствах и середовищах; 
Журнал«Герспективитаіновації наукиљ

(Серія«Гедагогіка», Серія«ГЕихологія», Серія«Медицина»

№1(6) 2022

уміннями та навичками, а саме: здатність виявляти свої можливості, зосереджуватися, долати складнощі, критично мислити та ухвалювати рішення; здатність конструктивно спілкуватись у різних середовищах, співпрацювати в команді та вести переговори; ставленнями, як-то: толерантність, висловлювання та розуміння різних точок зору, спроможність створювати атмосферу довіри та співчувати; готовність до співпраці, наполегливість та чесність; повага до інших та готовність як долати забобони, так і йти на компроміс [3].

Розглядаючи соціальну компетентність М. І. Лук’янова зазначає, що вона $\epsilon$ особистісним утворенням, свідомим вираженням особистості, що виявляється в їі переконаннях, поглядах, стосунках, мотивах, установках на певну поведінку, у сформованих особистісних якостей, що сприяють конструктивній взаємодії [4].

Таким чином, соціальна компетентність виявляється у соціальній поведінці людини, що визначається соціальною ситуацією, існуючими соціальними нормами та правилами, а також цінностями людини, її цілями та обраними способами і засобами їх досягнення.

Поняття «громадянська компетентність», введено кілька років, тому у науковий обіг у зв'язку з розвитком компетентнісного підходу до визначення цілей та якості освіти. Однак у більшості досліджень (Г. Я.Гревцева, I. А. Зимної, Р. Даля та ін.) поняття громадянської компетентності розглядається або у зв'язку з проблемами громадянського виховання, або у зв’язку з проблемою компетентнісного підходу в широкому розумінні слова.

Одним із перших українських педагогів, хто звернувся до громадянського виховання, як до ключової педагогічної проблеми був Василь Сухомлинський, який визначив «підлітковий вік як особливо важливий для формування громадянина» і твердив, що «риси громадянина виховуються безліччю впливів педагогічного характеру й некерованими соціальними впливами» [5].

Педагог зауважував, що «задовго до повноліття наш підліток має жити громадянськими думками й сприйманнями», а «справжне громадянське виховання у процесі навчання починається там, де думка надихає, пробуджує й утверджує прагнення до морального ідеалу» [6].

У сучасному світі громадянська освіта підростаючого покоління $\epsilon$ предметом інтересу державних структур, громадських діячів і організацій національного та міжнародного масштабу, фахівців у галузі освіти. Вітчизняні дослідники модифіковано підходять до визначень і трактувань громадянської освіти. Вони вважають, що у сучасних умовах громадянська освіта має на меті підготовку молоді до активної участі в житті демократичного суспільства й розвитку демократичної культури.

Важливим є акцентування уваги на становленні громадянських цінностей підростаючого покоління в сучасному глобальному світі, що характеризується різким посиленням взаємопроникнення культур. У контексті трансформації ціннісних орієнтирів значно зростає роль освіти в громадянському становленні 
української молоді.

Результатом громадянської освіти має стати сформованість у підростаючого покоління громадянської компетентності як складного особистісного утворення. На думку вітчизняних дослідників, громадянська компетентність передбачає такі здатності: орієнтуватися у проблемах сучасного суспільно-політичного життя в Україні, знати процедури участі в діяльності політичних інститутів демократичної держави, органів місцевого самоврядування; застосовувати процедури й технології захисту власних інтересів, прав і свобод своїх та інших громадян; виконувати громадянський обов’язок у межах місцевої громади та держави загалом; застосовувати способи і стратегії взаємодії з органами державної влади на користь собі й громадянському суспільству; використовувати способи діяльності й моделі поведінки, що відповідають чинному законодавству України, задовольняють власні інтереси особи та захищають права людини й громадянина; робити свідомий вибір, застосовувати демократичні технології прийняття індивідуальних та колективних рішень, враховуючи інтереси й потреби громадян, представників певної спільноти, суспільства та держави [7].

Таким чином, сучасні вітчизняні дослідники під громадянською компетентністю розуміють здатність людини активно, відповідально й ефективно реалізовувати громадянські права та обов'язки з метою розвитку демократичного суспільства.

У Рекомендаціях Комітету міністрів РС визначено умови набуття молоддю європейських країн громадянської компетентності, які є актуальними й для України. До них належать: активна участь учнів, студентів, викладачів і батьків у демократичному управлінні навчальним закладом; демократизація методів навчання та виховання, взаємовідносин суб'єктів навчально-виховного процесу; поширення методів, орієнтованих на особистість учні і студента, зокрема, реалізація педагогічних проєктів, що грунтуються на спільній колективній меті та співпраці учасників, які опікуються освітою 3 питань демократичного громадянства (неурядові установи, підприємства, професійні організації); сприяння дослідженням, індивідуальному навчанню та ініціативі; формування освітніх підходів, що тісно пов’язують теорію 3 практикою; залучення учнів і студентів до індивідуального та колективного оцінювання якості навчання, зокрема, в рамках педагогічних проєктів; заохочення обмінів, зустрічей i партнерства між учнями, студентами та вчителями 3 різних навчальних закладів з метою поліпшення міжособистісного взаєморозуміння; поширення підходів і методів освіти, що сприяють вихованню в суб'єктів навчально-виховного процесу толерантності і поваги до культурної та релігійної багатоманітності; зближення формальної та неформальної освіти; встановлення відносин громадянського партнерства між школою та сім'єю, громадою, трудовим колективом і 3МI [8].

Таким чином, проаналізувавши теоретичні напрацювання у галузі громадянської освіти, громадянської компетентності ми погоджуємося 3 
Журнал«Герспективитаіновації наукиљ

(Серія«Гедагогіка», Серія«Гтихологія», Серія«Медицинв»

№1(6) 2022

визначенням, що громадянська компетентність - це інтегративна якість особистості, що дозволяє їй усвідомлено, відповідально і ефективно користуватися громадянськими правами та свободами, виконувати обов'язки громадянина, займати активну громадянську позицію, поділяти цінності демократичного суспільства, бути патріотом своєї Батьківщини, шанобливо ставитися до народів і культур інших країн [9].

Отже, проблема формування соціальної та громадянської компетентностей, насамперед у здобувачів початкової освіти, пошук дієвих засобів та способів пї досягнення $є$ однією 3 найважливіших у сучасному вихованні учнівської молоді.

Молодший шкільний вік - період дитинства, етап розвитку дитини, що відповідає періоду навчання у початковій школі (6 - 10 років). 3 приходом дитини до школи відбувається перебудова всієї системи відносин дитини 3 дійсністю, вона починає здійснювати суспільно значиму і оцінювану діяльність [10]. Молодший шкільний вік є початком суспільного буття дитини як суб’єкта діяльності. У процесі діяльності відбувається накопичення знань про життя суспільства, взаємовідносини між людьми, про свободу вибору того чи іншого способу поведінки. Щоб діяльність мала запланований результат у формуванні основ соціальної та громадянської позиції молодшого школяра, иiі треба розумно направити дорослому, організуючи як спільно розподілену, колективну [11]. Основною функцією вчителя є створення сприятливих умов для: первісних уявлень про людину як частину громадянського суспільства, про права та відповідальність людини перед оточуючими: гідності та правам своїх та інших людей; здібності до прояву взаємодопомоги, конструктивного спілкування, до спільної діяльності 3 дорослими та однолітками; про морально-етичні норми поведінки та міжособистісні відносини; переваг у ситуаціях вибору на користь морально-етичних норм; позитивний досвід дотримання правил повсякденного етикету, дисципліни в освітній організації; прояви доброзичливості, толерантності, неприйняття будь-яких форм поведінки, спрямованої на заподіяння фізичної та моральної шкоди іншим людям; виховання поваги традицій свого народу, любові до Батьківщини, малої Батьківщини; прояви дій та вчинків школярів в аспекті соціальних та громадянських цінностей [12]. У відношенні до інших людей проявляється дитяча чутливість до оцінки своєї соціальної активності, коло людей, оцінки яких стають важливими для дитини, значно розширюється. Ставлення себе виявляється у загостреному почутті самоповаги, у переживанні своєї значимості інших як рівноправного партнера [13].

Соціальна та громадянська позиція здобувача початкової освіти нами розглядається, як якість особистості, що $є$ складною багатофункціональною системою, що включає здатність до осмислення понять і оволодіння знаннями про соціальні та громадянські цінності (Батьківщина, сім'я, людина,), на основі емоційно-чуттєвого сприйняття та стійкого ставлення до них та визначальна дії та вчинки тих, хто навчається в аспекті громадянських цінностей. 
У своєму дослідженні ми звертаємося до шкільного курсу «Я досліджую світ» як засобу формування основ соціальної та громадянської позиції здобувача початкової освіти. Для досягнення мети - формування засад соціальної та громадянської позиції здобувача початкової освіти у курсі «Я досліджую світ» - було сформульовано такі завдання: забезпечення здатності до осмислення понять та оволодіння знаннями про соціальні та громадянські цінності (Людина, Сім'я, Батьківщина тощо); формування усвідомленого прийняття цінностей та стійке емоційно-чуттєве ставлення до них.

Реалізація моделі формування основ соціальної та громадянської позиції здобувача початкової освіти у курсі «Я досліджую світ» неможлива без використання інноваційних методів та форм. Погоджуючись 3 думкою вчених (Б. Т. Лихачов [14], І. П. Подласий [15] та ін.), вважаємо за доцільне використання наступних груп методів: методи формування свідомості (оповідання, переконання, бесіда, інструктаж, диспут, повідомлення, приклад тощо); методи організації діяльності та формування досвіду поведінки (вправа, привчання, громадська думка, доручення, що виховують ситуації, дослідження, проєктна робота тощо); методи стимулювання та мотивації діяльності (змагання, заохочення); методи контролю, самоконтролю, оцінки та самооцінки діяльності та поведінки. За допомогою цих методів створюється атмосферу співтворчості та співробітництва, яка залучає і педагога, і тих, хто навчається до творчої діяльності з розвитку своєї особистості. У зв'язку 3 методами формування основ соціальної та громадянської позиції перебувають iii форми. Провідною формою є урок. Великим потенціалом у формуванні основ соціальної та громадянської позиції здобувача початкової освіти $\epsilon$ інтегровані уроки, перевага яких полягає в тому, що вони сприяють із різних боків пізнавати явище, предмет.

Висновки. У сучасному світі суспільству та державі потрібні компетентні та освічені громадяни, відповідальні та креативні. 3 урахуванням соціальноекономічних викликів саме системі освіти належить визначальна роль формування соціальної та громадянської компетентностей як інтегральних суб'єктних якостей особистості (свідома громадянська позиція, світогляд, уміння приймати самостійні рішення, брати участь у самоврядуванні тощо), які визначають їі ефективну соціалізацію.

\section{Jimepamvpa:}

1. Гаязов А. С. Образование и образованность гражданина в современном мире. Москва : Наука, 2003. 256 с.

2. Дубасенюк О. А. Компетентнісний підхід у професійній підготовці вчителя / О. А. Дубасенюк. Формування естетичної компетентності особистості засобами народознавства : зб. наук. пр. Житомир, 2010. С. 10-16.

3. Рекомендації ради Європи щодо ключових компетентностей для освіти впродовж життя від17.01.2018p. Режим доступу: https:/ec.europa.eu/education/sites/education/files/ recommendation-key-competences-lifelong-learning.pdf

4. Лукьянова М. И. Социальная компетентность как компонент управленческой культуры руководителя / М. И. Лукьянова. Психология инноваџионного управления сочиальными группами и организащиями. Кострома, 2001. С. 240-242. 
5. Громадянин - Держава - Громадянське виховання. Антологія / за ред. М. А. Рогозін, О. В. Сухомлинська. Донецьк, 2001. С. 213.

6. Сухомлинский В. А. Рождение гражданина. Москва, 1971. 336 с.

7. Компетентнісний підхід у сучасній освіті : світовий досвід та українські перспективи / за ред. Н. М. Бібік, Л. С. Ващенко, О. І. Локшина, О. В. Овчарук, Л. І. Паращенко, О. І. Пометун, О. Я. Савченко, С. Є. Трубачова. Київ : Видавництво «К.І.С.», 2004. 112 с.

8. Громадянська освіта : метод. посіб. Київ : Видавництво Етна-1, 2008. 194 с.

9. Степанова Н. М. Формування громадянської компетентності учнів загальноосвітніх навчальних закладів у відповідно до вимог нових державних освітніх стандартів : навчметод. посіб. Черкаси : Видавництво Черкаського обласного інституту післядипломної освіти педагогічних працівників Черкаської обласної ради, 2014. 44 с.

10. Эльконин Д. Б. Детская психология : учеб. пособ. Москва : Издательский центр «Академия», 2007. 384 с.

11. Давыдов В. В., Слободчиков В. И., Цукерман Г. А. Младший школьник как субъект учебной деятельности. Вопросы психологии. 1992. № 3-4. С. 14-19.

12. Рожков М. И., Байбородова Л. В. Теория и методика воспитания. Москва, 2004. 208 с.

13.Слободчиков В. И., Исаев Е. И. Психология образования человека. Становление субъектности в образовательных процессах. Москва : Изд-во Православного Свято-Тихоновского гуманитарного университета, 2014.

14. Лихачев Б. Т. Педагогика. Москва : Прометей, 1992. 528 с.

15. Подласый И. П. Педагогика. Москва, 2013. 696 с.

\section{References:}

1. Gajazov, A. C. (2003). Obrazovanie i obrazovannost' grazhdanina v sovremennom mire [Education and education of the citizen in the modern world]. Moskva : Nauka [in Russian].

2. Dubasenjuk, O. A. (2010). Kompetentnisnij pidhid u profesijnij pidgotovci vchitelja [Competence approach in the professional training of teachers]. Formuvannja estetichnoï kompetentnosti osobistosti zasobami narodoznavstva - Formation of aesthetic competence of the individual by means of ethnography, 10-16 [in Ukrainian].

3. Rekomendaciï radi Evropi shhodo kljuchovih kompetentnostej dlja osviti vprodovzh zhittja [Recommendations of the Council of Europe on key competences for lifelong learning]. ec.europa.eu. Retrived from https://ec.europa.eu/education/sites/education/files/ recommendation-key- competences-lifelong-learning.pdf [in Ukrainian].

4. Luk'janova, M. I. (2001). Social'naja kompetentnost' kak komponent upravlencheskoj kul'tury rukovoditelja [Social competence as a component of managerial culture of the leader]. Psihologija innovacionnogo upravlenija social'nymi gruppami i organizacijami Psychology of innovative management of social groups and organizations, 240-242 [in Russian].

5. Rogozin, O. V., Suhomlins'ka, M. A. (2001). Gromadjanin-Derzhava-Gromadjans'ke vihovannja. Antologija [Citizen - State - Civic education. Anthology]. Donec'k [in Ukrainian].

6. Suhomlinskij, V. A. (1971). Rozhdenie grazhdanina [Birth of a citizen]. Moskva [in Russian].

7. Bibik, N. M., Vashhenko, L. S. , Lokshina, O. I. , Ovcharuk, O. V., Parashhenko, L. I., Pometun, O. I. , Savchenko, O. Ja. , Trubachova, S. E. (2004). Kompetentnisnij pidhid u suchasnij osviti: svitovij dosvid ta ukraïns'ki perspektivi [Competence approach in modern education: world experience and Ukrainian prospects]. Kiïv : Vidavnictvo «K.I.S.» [in Ukrainian].

8. Gromadjans'ka osvita [Civic education]. Kiïv : Vidavnictvo Etna-1 [in Ukrainian].

9. Stepanova, N. M. (2014). Formuvannja gromadjans'koï kompetentnosti uchniv zagal'noosvitnih navchal'nih zakladiv u vidpovidno do vimog novih derzhavnih osvitnih standartiv [Formation of civic competence of students of secondary schools in accordance with the requirements of new state educational standards]. Cherkasi. Vidavnictvo Cherkas'kogo oblasnogo institutu pisljadiplomnoï osviti pedagogichnih pracivnikiv Cherkas'koï oblasnoï radi [in Ukrainian]. 
10. Jel'konin, D. B. (2007). Detskaja psihologija [Child psychology]. Moskva : Izdatel'skij centr «Akademija» [in Russian].

11. Davydov, V. V., Slobodchikov, V. I., Cukerman, G. A. (1992). Mladshij shkol'nik kak sub\#ekt uchebnoj dejatel'nosti [Junior student as a subject of educational activity]. Voprosy psihologii - Questions of psychology, 3-4, 14-19 [in Russian].

12. Rozhkov, M. I., Bajborodova, L. V. (2004). Teorija i metodika vospitanija [Theory and methods of education]. Moskva [in Russian].

13. Slobodchikov, V. I., Isaev, E. I. (2014). Psihologija obrazovanija cheloveka. Stanovlenie sub\#ektnosti $v$ obrazovatel'nyh processah [Psychology of human education. Formation of subjectivity in educational processes]. Moskva : Izd-vo Pravoslavnogo SvjatoTihonovskogo gumanitarnogo universiteta [in Russian].

14. Lihachev, B. T. (1992). Pedagogika [Pedagogy]. Moskva : Prometej [in Russian].

15. Podlasyj, I. P. (2013). Pedagogika [Pedagogy]. Moskvva [in Russian]. 